\title{
THE STRUCTURE AND THE EMBRYOGENETIC ROLE OF EGGS AND EGG MEMBRANES OF ANCISTRUS DOLICHOPTERUS (ACTINOPTERYGII: SILURIFORMES: LORICARIIDAE)
}

\author{
Adam BRYSIEWICZ ${ }^{1}$, Joanna SZULC ${ }^{2}$, Krzysztof FORMICKI ${ }^{2 *}$, Adam TAŃSKI ${ }^{2}$, \\ and Agata KORZELECKA-ORKISZ ${ }^{2}$ \\ ${ }^{1}$ West Pomeranian Research Center in Szczecin, Institute of Technology and Life Science, Szczecin, Poland \\ 2 Division of Fish Anatomy, Hydrobiology, and Biotechnology of Reproduction, \\ West Pomeranian University of Technology in Szczecin, Szczecin, Poland
}

\begin{abstract}
Brysiewicz A., Szulc J., Formicki K., Tański A., Korzelecka-Orkisz A. 2011. The structure and the embryogenetic role of eggs and egg membranes of Ancistrus dolichopterus (Actinopterygii: Siluriformes: Loricariidae). Acta Ichthyol. Piscat. 41 (3): 223-227.
\end{abstract}

\begin{abstract}
Background. Bushymouth catfish, Ancistrus dolichopterus Kner, 1854 has raised interest among ornamental fish keepers. Its natural populations are seriously threatened by fishing pressure. The reproduction of this species is difficult to perform (in captivity) and to observe because it occurs at night in shaded areas - most frequently in hiding spots. This study was intended to describe the eggs and their membranes of bushymouth catfish known to provide a parental care during egg development. A special focus of this study was directed towards the microstructure of membranes protecting life cells, and known to be impacted by the environmental conditions the egg morphometric analysis, as well as embryonic development.

Materials and methods. The material for the study consisted of the eggs of 3 pairs of bushymouth catfish obtained as a result of their spawning in an aquarium culture. The fertilised eggs were incubated at a constant temperature of $24 \pm 0.2^{\circ} \mathrm{C}$ in water of hardness $17^{\circ} \mathrm{n}, \mathrm{pH} 6.5$. The utrastructural details of egg membranes were viewed under scanning electron microscope (SEM). Also egg membrane resistance and egg diameters were determined. Images of eggs and newly hatched larvae were measured and analysed.

Results. Average egg diameter was $2.98 \mathrm{~mm}$ and surface-to-volume ratio $(S / V)$ was 2.01. Internal and external layers of egg membranes showed various structure peculiarities in the surface microstructure of studied eggs. We found that in comparison to other fish the thickness of egg membrane in the bushymouth catfish was high $(26.05 \mu \mathrm{m})$. External layer had no pores leading to external radial zone (zona radiata externa), however, some specific honeycomb-like formations were visible. The resistance of the egg membrane was $54 \pm 1.7 \mathrm{~g}$ and the egg mass was $0.017 \pm 0.0001 \mathrm{~g}$. The correlation between the resistance and the thickness of the egg membranes was not high, but the correlation between the mass and the resistance was significant.

Conclusion. The presently reported study constitutes a contribution to the knowledge of the eggs and embryonic development of bushymouth catfish, and its biological sense, emphasizing the morphophysiological differences between this species - living under, specific, diversified ecological conditions. Such knowledge on early developmental stages may be prove helpful in the fish culturist's practice of this threatened and interesting species.
\end{abstract}

Keywords: Ancistrus, egg membranes, eggs, aquarium

\section{INTRODUCTION}

Genus Ancistrus is represented by fish commonly known as bushymouth or bristlenose plecos. They occur in the watershed of upper Amazon including Peruvian Ucayali and less frequently in the lower Amazon watershed (Kornobis 1990). The fish of this genus living in the wild can reach up to $15 \mathrm{~cm}$ of length, whereas in the captivity (culture) they do not exceed $13 \mathrm{~cm}$ (Riehl and Baensch 1996). Adults show sexual dimorphism, the juveniles look the same despite their sex.
The reproduction of bushymouth catfish, Ancistrus dolichopterus Kner, 1854, is difficult to observe because it occurs at night in shaded areas - most frequently in hiding spots. The male prepares so called "pseudo-nest" before female would lay the eggs. He carefully cleans the nest and protects it from invasion of any potential predators e.g., snails. This specific care fulfilled only by the male lasts during the entire embryonic development till the larvae leave the nest, move independently, and are able to feed themselves (Rymkiewicz 1988).

\footnotetext{
${ }^{*}$ Correspondence: Prof. dr hab. Krzysztof Formicki, Katedra Anatomii, Hydrobiologii i Biotechnologii Rozrodu, Zachodniopomorski Uniwersytet Technologiczny, ul. Kazimierza Królewicza 4, 71-550 Szczecin, Poland, phone: +4891449 6665, e-mail: krzysztof.formicki@zut.edu.pl.
} 
During spawning the female can lay from 30 to more than 100 eggs, on average $3.1 \mathrm{~mm}$ in diameter. Thick and non-transparent membrane of eggs makes it impossible to observe the embryonic development (Rymkiewicz 1988). According to Petrovický (1985) the embryonic development of A. dolichopterus takes $94^{\circ} \mathrm{D}$ (degree-days) at water temperature of $25^{\circ} \mathrm{C}$.

Fish eggs contain the central (living) part which constitutes of the cytoplasm contained inside the semipermeable vitelline membrane. This living part contains the genetic material, large portion of the storage material (yolk), and is protected by the egg membranes and envelopes.

Zona radiata of any species within the bony fishes is constructed of two layers: the thin external layer (zona radiata externa i.e., ZRE) and the thicker internal layer (zona radiata interna i.e., ZRI) (Balon 1977, Riehl 1991, Riehl and Patzner 1998). Modern technologies such as scanning electron microscopy (SEM), make it possible to find family- and species-specific variability in the thickness and structure of these layers. These layers undergo structural modification upon activation and fertilization of the egg (Johnson and Werner 1986, Lönning 1972, Mayer et al. 1988, Yamamoto and Yamagami 1975). It is also known that the structure and thickness of egg protective membranes results from specific reproductive ecology of given fish species (Stehr and Hawkes 1979). To our knowledge, there is no available literature discussing the structure of egg membranes of fish providing parental care such as the bushymouth catfish. This study was motivated by the lack of any publications discussing egg membrane structures of the bushymouth catfish and we are providing information referring to some of these aspects. In this study we focus on microstructure of the layers surrounding the living tissue and morphometrics of the deposited eggs, assuming that these characteristics are strongly influenced by the environment in which the embryo develops.

\section{MATERIALS AND METHODS}

The material for the study consisted of the eggs of 3 pairs of bushymouth catfish, Ancistrus dolichopterus, obtained as a result of their natural spawning in an aquarium.

Three spawning pairs were bred in three 60 -L tanks at water temperature of $24^{\circ} \mathrm{C}, \mathrm{pH}$ of 6.5 , and total hardness of $17^{\circ} \mathrm{n}$. A hiding spot (coconut membrane) was provided as a substrate for laying eggs and its inside was carefully cleaned by the male. Inside the shell, each female laid the average of 121 eggs, which were fertilized there.

The eggs were lumped in the form of a cluster. During the entire embryonic development, the male was taking care by protecting the developing eggs and constantly fanning them with its pectoral fins, which provided optimal oxygen conditions (Fig. 1).

Hatched larvae were also protected by the male, who was constantly swimming around the nest, until the yolk sacs in the developing larvae would disappear completely (Fig. 2).

Samples of fertilized and swollen eggs $(n=20)$ were subjected to the following tests:
- Egg membrane ultrastructure using scanning electron microscopy (SEM). Prior to SEM eggs were first fixed in $4 \%$ formaldehyde, and secondly dehydrated in a series of alcohol and acetone washes. Dried eggs were attached to a stub and sputter-coated with a thin layer of gold and palladium alloy. Prepared samples were observed using scanning electron microscope (JEOL JSM 6100) and images were saved for further image analyses. Egg-membrane thickness and pore diameter were measured by using image analysis software NIS Element Br.

- The dimensions of oval in shape egg were determined using a setup consisting of light microscope (Nicon Eclipse TE $2000 \mathrm{~S}$ ) connected to digital camera (Nikon DS-5Mc-UZ), monitor. Egg volume $(V)$ and surface area $(S)$ was calculated using two diameter measurements $\left(r_{1}\right.$ and $\left.r_{2}\right)$ :

$$
\begin{gathered}
V=4 / 3 \pi r_{1} r_{2}{ }^{2} \\
S=4 \pi r_{1} r_{2}
\end{gathered}
$$

and these parameters were used to calculate the egg surface to volume $(S / V)$ ratio.

- Egg-membrane resistance was measured using a setup consisting of WPE 10 electronic balance equipped with a memory function that recorded the maximum pressure (membrane strength) and a devise making it possible to change the pressure continuously. The test was carried out on 20 randomly selected eggs. Each egg was tested separately using two flat surfaces, $(20 \times 20 \mathrm{~mm})$, approaching at a speed of $1 \mathrm{~mm} \cdot 1 \mathrm{~s}^{-1}$.

Detailed observation of embryonic development was not possible due to the opaque egg membrane. Statistical analyses (test of correlation and regression) were conducted using Statistica ${ }^{\circledR}$ 8.1.PL software.

The presently reported study has been carried out in accordance with the Polish regulations on experiments on animals.

\section{RESULTS}

SEM examination indicated pronnunced differences in the surface microstructure. A division into two layers was visible in the cross-section of the egg membrane (Fig. 3), where strictly ordered canal outlines penetrating through the internal membrane layer were visible only in the base part, while the top part, $80 \%$ of the membrane, did not show distinct structural arrangement.

While it is impossible to see any pores penetrating into the external zone (zona radiata externa) and, even with $2500 \times$ magnification (Fig. 4), only a certain kind of unordered, structural honeycombs was visible, the internal side being distinctly and regularly perforated by canals penetrating inside the internal zone of the membrane (zona radiata interna) in the amount of 23 per $25 \mu^{2}$ (Fig. 5).

The thickness of the egg membrane in bushymouth catfish was $26.05 \mu \mathrm{m}$.

The resistance of the egg membrane in bushymouth catfish was $54 \pm 1.7 \mathrm{~g}$ and the egg mass was $0.017 \pm 0.0001 \mathrm{~g}$.

A correlation was reported between the resistance and the thickness of the egg membranes in bushymouth catfish $(R=0.08)$, which was not high. However, the correlation between the mass and the resistance $(R=0.23)$, was significant. 
The diameter $(d)$ of the swollen eggs was on average $2.98 \pm 0.02 \mathrm{~mm}$. At $24^{\circ} \mathrm{C}$ the embryonic development lasted $102^{\circ} \mathrm{D}$. The egg volume $(V)$ was on average $14.04 \pm 0.23 \mathrm{~mm}^{3}$ and its surface area $(S) 28.11 \pm 0.32 \mathrm{~mm}^{2}$. The $S / V$ parameter, directly related to the metabolism in the tissues conditioning the pace of the embryogenesis and time of embryonic development, was on average $2.01 \pm 0.01 \mathrm{~mm}^{-1}$.

\section{DISCUSSION}

The presently reported study contributed a number of new data on the egg-membrane microstructure in the bushymouth catfish.

The general structure of an egg of the bushymouth, particularly the membrane ultrastructure, is related to the nature of the substrate on which the eggs are deposited. What is worth noticing is the fact of relatively high fertility of examined specimens (over 100 eggs laid by one female), which significantly exceeds the respective values reported by other authors (Petrovický 1985, Rymkiewicz 1988). This may be explained with mature age, which complies with the opinion that individual fertility increases with the age of bushymouth catfish (Rymkiewicz 1988).
SEM observations of the egg membranes indicated that certain formations, resembling "honeycomb", were visible in the microstructure of the external zone (zona radiata externa). Similarly, but more visibly, such structures can be found in egg membranes of ruffe, Gymnocephalus cernua (L.), (see Patzner and Glechner 1996); red piranha, Pygocentrus nattereri Kner, 1858, (see Riehl 1995), and speckled piranha, Serrasalmus spilopleura Kner, 1858 (see Rizzo et al. 2002) as well as in saltwater fish such as: silvery lightfish, Maurolicus muelleri (Gmelin, 1789), (see Robertson 1981). Such a specific external egg- membrane structure in bushymouth catfish fosters fastening or better adherence to substrate irregularities (hard surfaces).

The inside of the membrane is distinctly and regularly perforated with canals penetrating into the internal zone (zona radiata interna). Such pores are also found in other fish species, e.g., silver carp, Hypophthalmichthys molitrix (Valenciennes, 1844), with pore diameter of $0.026 \mu \mathrm{m}$ (Esmaeli and Johal 2005) and blackhead seabream, Acanthopagrus schlegelii (Bleeker, 1854) — with 0.17- $\mu$ m pores (Gwo 2008).

The egg membrane of $A$. dolichopterus is relatively thick - 26.05 $\mu \mathrm{m}$ - as compared to other fish species.
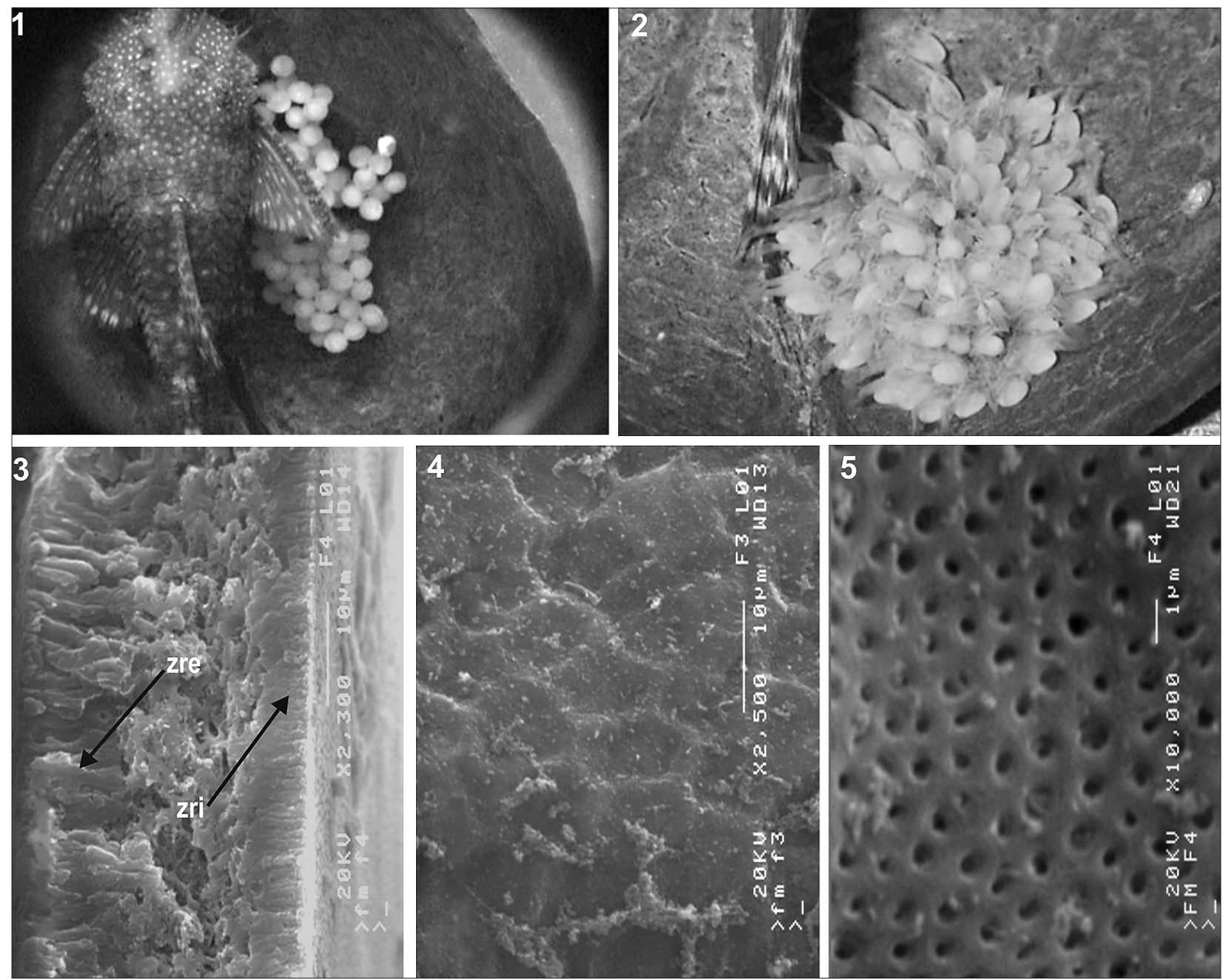

Figs. 1-5. Bushymouth catfish, Ancistrus dolichopterus; Fig. 1. A male guarding the developing eggs; Fig. 2. Newly hatched larvae; Fig. 3. Cross-section of egg membrane $(\times 2300)$; ZRE $=$ zona radiata externa, ZRI $=$ zona radiata interna; Fig. 4. External side of the egg membrane $(\times 2500)$; Fig. 5. Internal side of egg $(\times 10000)$ 
For comparison, the membrane thickness in a number of fish is as follows: lumpfish, Cyclopterus lumpus L., -50 $\mu \mathrm{m}$; European plaice, Pleuronectes platessa L.,-20 $\mu \mathrm{m}$; capelin, Mallotus villosus (Müller, 1776),-10 $\mu \mathrm{m}$ (Davenport et al. 1986); Dalmatian barbelgudgeon, Aulopyge huegelii Heckel, 1843,- - from 3.2 through $5.5 \mu \mathrm{m}$ (Bless and Riehl 2002); silver carp, Hypophthalmichthys molitrix (Valenciennes, 1844), -5.86 $\mu \mathrm{m}$ (Esmaeli and Johal 2005); pond loach, Misgurnus anguillicaudatus (Cantor, 1842),-2.0 $\mu \mathrm{m}$; Misgurnus mizolepis Günther, 1888-3.0 $\mu \mathrm{m}$ (Kim and Park 1996); trahira, Hoplias malabaricus (Bloch, 1794),-3.92 $\mu \mathrm{m}$ (Gomes et al. 2007); Barbatula toni (Dybowski, 1869) -from 4.0 through $5.0 \mu \mathrm{m}$ (Kim and Park 1996); silvery lightfish, Maurolicus muelleri (Gmelin, 1789),--from 0.01 through $0.02 \mu \mathrm{m}$ (Robertson 1981); cardinal fish, Apogon imberbis (L.),-1.2 $\mu \mathrm{m}$ (Lahnsteiner 2003).

The egg membrane resistance in bushymouth catfish is $54 \pm 8.0 \mathrm{~g}$. The values are comparable with the values obtained for certain saltwater fish such as e.g., European plaice, Pleuronectes platessa L.,-35.2 g, lumpfish, C. lumpus, - $107.5 \mathrm{~g}$ (Davenport et al. 1986) and, on the other hand, much lower than the resistance characteristic for the species laying eggs during spawning in a spawning redds, covered by the gravel such as e.g., salmonid fish (Sobociński and Winnicki 1974, Formicki 1986, Iuchi et al. 1996).

What must also be mentioned here is a certain problem regarding the size of eggs in bushymouth catfish, which in comparison to other mature fish, are relatively big. This involves the whole egg surface and, thus, the dimensions of the egg membrane. Its dimensions influence the volume of the egg inside, where the oocyte ectoplasm, the yolk, the nucleus, and the place for perivitelline space will be located (Davenport et al. 1986, Makeeva and Pavlov 2000, Korzelecka-Orkisz et al. 2005, 2006). The egg size is mainly determined by technical conditions in which the spawning event and later the embryogenesis take place. If it is assumed that the speed of biochemical transformations of the embryo developing inside the egg depends on its access to oxygen from the external environment, while the speed of diffusion and the quantity of diffusing gas depend on the difference in partial pressure on both sides of the membrane as well as on the surface through which the diffusion occurs, the value of $S / V$ coefficient specifying the surface-to-volume ratio is of great importance. It makes it possible to specify the correlation between the speed of embryo development and the value of this coefficient determining the respiratory efficiency of the structures surrounding the developing embryo (Bonisławska unpublished*).

If eggs are larger (less favourable $\mathrm{S} / \mathrm{V}$ coefficient), which is the case of bushymouth catfish, the oxygen diffusion into the egg inside takes place more slowly and, thus, the speed of energy transformation and morphogenesis is lower. This might be attributed to the specific male's behaviour during the embryo development. The male constantly fans the eggs while taking care of them.
Such behaviour facilitates better aeration and creation of optimal conditions for the developing embryos.

There are, however, rare exceptions from the above rule like e.g., the eggs of bighead carp, Aristichthys nobilis (Richardson, 1845), and grass carp, Ctenopharyngodon idella (Valenciennes, 1844). The eggs look large with the diameter of $4.8 \mathrm{~mm}$, but the oocytes located inside the egg membranes (diameter: $1.3-1.4 \mathrm{~mm}$ ) do not differ in size from other cyprinid fish species and the huge perivitelline space taking up $97 \%-98 \%$ of the whole egg volume is one of the adjustments allowing the eggs to float in the water column (Makeeva and Pavlov 2000, Bonisławska unpublished*).

Specific lumping of the deposited eggs allows the male to take care of all the eggs better, which increases the survival rate practically to a maximum. Such behaviour allows for the survival of a larger percentage of fertilized eggs in spite of relatively low individual fecundity in bushymouth catfish. In comparison to other fish species with certain forms of care over the eggs and larvae living in the same environment (e.g., Characidae), the bushymouth catfish developed a specific type of natural individual care of the eggs and the progeny by safeguarding them from predators and removing dead eggs (Rymkiewicz 1988, Riehl and Patzner 1991, Secutti and Trajano 2009). Fertility is much lower in fish not taking care of their eggs, which are laid in a larger area. The survival percentage is, thus, lower although the final amount of fry is similar in both cases.

The observed structural peculiarities as well as characteristic behaviour indicate that bushymouth catfish, like representatives of other species in the fish class, developed numerous adaptive mechanisms in the process of evolution, which allow them to live and reproduce freely in highly diversified environmental conditions.

\section{REFERENCES}

Balon E.K. 1977. Early ontogeny of Labeotropheus Ahl, 1927 (Mbuna, Cichlidae, Lake Malawi), with a discussion on advanced protective style in fish reproduction and development. Environmental Biology of Fishes 2: 147-176.

DOI: 10.1007/BF00005370

Bless R., Riehl R. 2002. Biology and egg morphology of the Dalmatian barbelgundgeon Aulopyge hugely, an endangered endemic species in Croatia. Environmental Biology of Fishes 63: 451-456. DOI: 10.1023/A:1014992626062

Davenport J., Lønning S., Kjørsvik E. 1986. Some mechanical and morphological properties of the chorions of marine teleost eggs. Journal of Fish Biology 29: 289-301. DOI: $10.1111 / \mathrm{j} .1095-8649.1986 . t b 04946 . x$

Esmaeili H.R., Johal M.S. 2005. Ultrastructural features of the egg envelope of silver carp, Hypophthalmichthys molitrix (Osteichthyes, Cyprrinidae). Environmental Biology of Fishes 72: 373-377. DOI: 10.1007/s10641-004-2589-y

Formicki K. 1986. The effect of magnetic fields on resistance of egg membranes in some salmonid fish. Polskie Archiwum Hydrobiologii 33 (1): 105-114.

Gwo H.H. 2008. Morphology of the fertilizable mature egg in the Acanthopagrus latus, A. schlegeli and Sparus sarba

\footnotetext{
${ }^{*}$ Bonisławska M. 2001. Wpływ temperatury na tempo i przebieg embriogenezy u ryb. [Temperature effects on the rate and course of embryogenesis in fish.] Praca doktorska [PhD thesis.] Akademia Rolnicza w Szczecinie. [Agricultural University of Szczecin.] Szczecin, Poland. [In Polish.]
} 
(Teleostei: Perciformes: Sparidae). Journal of Microscopy. 232: 442-452. DOI: 10.1111/j.1365-2818.2008.02139.x

Iuchi I., Ha C.R., Sugiyama H., Nomura K. 1996. Analysis of chorion hardening of egg of rainbow trout, Oncorhynchus mykiss. Development, Growth and Differentiation 38: 299-306. DOI: 10.1046/j.1440-169X.1996.t01-2-00009.x

Johnson E.Z., Werner R.G. 1986. Scanning electron microscopy of the chorion of selected freshwater fishes. Journal of Fish Biology 29: 257-265. DOI: 10.1111/j.1095-8649.1986.tb04943.x

Kim I.S., Park J.Y. 1996. Adhesive membrane of oocyte in four loaches (Pisces: Cobitidae) of Korea. Korean Journal of Zoology 39: 198-206.

Kornobis S. 1990. Słodkowodne ryby akwariowe. [Fresh-water aquarium fishes.] Wydawnictwo Poznańskie, Poznań. [In Polish.]

Korzelecka-Orkisz A., Bonisławska M., Szulc J., Formicki K., Winnicki A. 2005. Morfomechaniczne osobliwości rozwoju zarodkowego miętusa (Lota lota (L.)). [Morphomechanical peculiarities of embryonic development of burbot, Lota lota (L.)] Pp. 163-169. In: Zakęś Z. (ed.) Rozród, podchów, profilaktyka ryb sumokształtnych i innych gatunków. [Reproduction, rearing, and prophylaxis of silurid- and other fishes.] Wydawnictwo IRŚ Olsztyn. [In Polish.]

Korzelecka-Orkisz A., Bonisławska M., Tański A., Szulc J., Formicki K., Winnicki A. 2006. Wybrane aspekty embriogenezy certy (Vimba vimba) w zróżnicowanych warunkach termicznych wody. [Selected aspects of vimba bream Vimba vimba embryogenesis under different thermal conditions.] Pp. 69-78 In: Zakęś Z. (ed.) Rozród, podchów, profilaktyka ryb karpiowatych i innych gatunków. [Reproduction, rearing, and prophylaxis of silurid- and other fishes.] Wydawnictwo IRŚ Olsztyn. [In Polish.]

Lahnsteiner F. 2003. The spermatozoa and eggs of the cardinal fish. Journal of Fish Biology 62: 115-128. DOI: $10.1046 / j .1095-8649.2003 .00012 . x$

Lönning S. 1972. Comparative electron microscopic studies of teleostean eggs with special reference to the chorion. Sarsia 49: 41-48.

Makeeva A.P., Pavlov D.S. 2000. Morfologičeskaâ harakteristika i osnovnye priznaki dlâ opredeleniâ ikry ryb presnyh vod Rossii. [Morphological characteristics and main features for determination of eggs of freshwater fishes of Russia.] Voprosy Ihtiologii 40 (6): 780-791. [In Russian.]

Mayer S., Shackley E., Ryland J.S. 1988. Aspects of the reproductive biology of the bass Dicentrarchus labrax. I. An histological and histochemical study of oocyte development. Journal of Fish Biology 33: 609-622.

DOI: $10.1111 / j .1095-8649.1988 . t b 05504 . x$

Patzner R.A., Glechner R. 1996. Attaching structures in eggs of native fishes. Limnologica. 26 (2): 179-182.
Petrovický I. 1985. Tropikalne ryby akwariowe. [Tropicalaquarium fishes.] PWRiL, Warszawa 1985. [In Polish.]

Robertson D.A. 1981. Possible functions of surface structure and size in some planktonic eggs of marine fishes. New Zealand Journal of Marine and Freshwater Research 15: 147-153.

Riehl R. 1991. Structure of oocytes and egg envelope in oviparous teleosts - an overview. Acta Biologica Benrodis 3: $27-65$.

Riehl R. 1995. Die Eier und Eihüllen der Knochenfischen. Fortpflanzungsbiologie der Aquarienfische. Birgit Schmettkamp Verlag, Bornheim.

Riehl R., Baensch H.A. 1996. Aquarien Atlas, Band 1. 10th edition. Mergus Verlag GmBH, Melle, Germany.

Riehl R., Patzner R.A. 1991. Breeding, egg structure and larval morphology of the catfish Sturisoma aureum (Steindachner) (Teleostei, Loricariidae). Journal of Aquariculture and Aquatic Sciences 6: 1-6.

Riehl R., Patzner R.A. 1998. Minireview: The modes of egg attachment in teleost fishes. Italian Journal of Zooloology 65 (suppl.): 415-420.

Rizzo E., Sato Y., Barreto B.P., Godinho H.P. 2002. Adhesiveness and surface patterns of eggs in neotropical freshwater teleosts. Journal of Fish Biology 61: 615-632. DOI: 10.1111/j.1095-8649.2002.tb00900.x

Rymkiewicz A. 1988. Uwagi o hodowli i rozmnażaniu ,glonojadów". [Remarks on breeding and reproduction of "algae eaters".] Magazyn Akwarium [On-line archive.] 2: (104) http://akwa-mania.mud.pl/archiwum/a104/a104.html. [In Polish.]

Secutti S., Trajano E. 2009. Reproductive behavior, development and eye regression in the cave armored catfish, Ancistrus cryptophthalmus Reis, 1987 (Siluriformes: Loricariidae), breed in laboratory. Neotropical Ichthyology 7 (3): 479-490.

Sobociński A., Winnicki A. 1974. Influence of $\mathrm{NaCl}$ solutions at various concentrations on hardening of egg membranes of trout Salmo trutta L. Acta Ichthyologica et Piscatoria 4 (2): $11-17$.

Stehr C.M., Hawkes J.W. 1979. The comparative ultrastructure of the egg membrane and associated pore structures in the starry flounder Platichtys atullatus (Pallas) and pink salmon Oncorhynchus gorbuscha (Walbaum). Cell and Tissue Research 202 (3): 347-356.

Yamamoto M., Yamagami K. 1975. Electron microscopic studies on choriolysis by the hatching enzyme of the teleost, Oryzias latipes. Developmental Biology 43: 313-321.

Received: 4 April 2011

Accepted: 23 September 2011

Published electronically: 30 September 2011 